\section{A made-in-Canada sugary drink levy can help reduce intake while being mindful of addressing health disparities}

Riediger and Bombak are correct that we must ensure that any levy on sugary drinks does not create unintended consequences or substantially widen social disparities. ${ }^{1}$ But the sugary drinks themselves contribute to those exact disparities, because the conditions they can cause - diabetes, heart disease, stroke, cancer and obesity - are highly regressive and disproportionately affect lowincome and Indigenous populations..$^{2-4}$

The reality for many Indigenous and northern communities is that food insecurity is high, ${ }^{5}$ and healthy options (fruit, vegetables and milk) can be more expensive and less available than energy-dense and nutrient-poor options. A head of cabbage or bunch of grapes can go for as much as $\$ 30$ or more, ${ }^{6,7}$ whereas a box of Kraft Dinner is more affordable at $\$ 4 .^{8}$ Cases of water can cost about $\$ 100,6,9$ whereas a 12 -can case of pop can cost $\$ 27,{ }^{10}$ representing a lower price per unit and a more accessible option for hydration. These price differences are exacerbated by the marketing practices of the manufacturers of sugary drinks, which, as Senator Dennis Patterson of Nunavut has told the Senate of Canada, extend even to very remote areas and to children as young as five years of age. ${ }^{11}$

We have a responsibility to act urgently and robustly, and a levy could help in a number of ways. In the United Kingdom, in anticipation of the Soft Drinks Industry Levy, manufacturers reduced the sugar content of some beverages even before the levy took effect in April 2018.12 In Mexico, the introduction of a levy was associated with a $10 \%$ reduction in sales of sugary drinks in the second year of implementation, with the greatest decline among low-income households. This levy was also associated with increases in the sales of nontaxed healthier products such as water. ${ }^{13}$

Although we know a levy on sugary drinks can work, it is also critical to ensure that Indigenous communities are meaningfully involved in the development and implementation of a levy and other policies that address the food supply. Indigenous Peoples should be consulted about how the revenues and proceeds from a levy could be used to facilitate an improved food supply, such as improving access to healthy foods and clean water. And in the spirit of selfgovernance, revenues from sales of sugary drinks on reserves could be given back to the communities to address the health needs they deem most important.

A levy is not the only solution to these challenges; however, if implemented well, it can be important and effective.

\section{Manuel Arango MA MHA}

Director, Health Policy \& Advocacy, Heart \& Stroke Foundation, Ottawa, Ont.

- Cite as: CMAJ 2018 August 20;190:E992. doi: $10.1503 / \mathrm{cmaj} .69859$

\section{References}

1. Riediger ND, Bombak AE. Sugar-sweetened beverages as the new tobacco: examining a proposed tax policy through a Canadian social justice lens. CMAJ 2018;190:E327-30.

2. Gionet $\mathrm{L}$, Roshanafshar S. Select indicators of First Nations people living off reserve, Metis and Inuit. Ottawa: Statistics Canada; 2013. Cat no 82-624-X. Available: www.statcan.gc.ca/pub/82-624-x /2013001/article/11763-eng.htm (accessed 2018 May 3).
3. Reading J. The crisis of chronic disease among Aboriginal peoples: a challenge for public health, population health and social policy. Victoria (BC): Centre for Aboriginal Health and Research/University of Victoria; 2009. Available: cahr.uvic.ca/nearbc/ documents/2009/CAHR-B2-Chronic-Disease.pdf (accessed 2018 May 3).

4. Health status of Canadians 2016, a report of the chief public health officer of Canada. Ottawa: Public Health Agency of Canada; 2016. Available: http:// healthycanadians.gc.ca/publications/department -ministere/state-pu (accessed 2018 May 3).

5. Galloway T. Canada's northern food subsidy Nutrition North Canada: a comprehensive program evaluation. Int J Circumpolar Health 2017;76:1279451.

6. Shenker L. Who, what, why: Why does a cabbage cost \$28 in Canada? BBC News 2012 June 14 Available: www.bbc.com/news/world-us-canada -18413043 (accessed 2018 May 3).

7. Beaumont H. Food prices are out of control in Northern Canada. Vice News 2016 Apr. 8. Available: news.vice.com/article/food-prices-are-out -of-control-in-northern-canada (accessed 2018 May 3).

8. Newman S. Sarah's blog. Oakville (ON): Feeding Nunavut. Available: www.feedingnunavut.com/ wp-content/uploads/2015/06/Sarahs-blog.png (accessed 2018 May 3).

9. Judd A. New campaign aims to shed light on the high cost of food in Canada's north. Global News 2016 Jan. 15. Available: globalnews.ca/news /2447177/new-campaign-aims-to-shed-light-on-the -high-cost-of-food-in-canadas-north/ (accessed 2018 May 3).

10. Murray J. Life in Northern Ontario depends on transportation. NNT NetNewsLedger 2014 Sept. 22. Available: www.netnewsledger.com/2014/09/22/ life-in-northern-ontario-depends (accessed 2018 May 3).

11. Patterson, Senator DG, Senate of Canada debates (Hansard). 42nd Parliament, 1st sess, 2017, vol. 150, issue 143 , third reading of Bill S-228.

12. Pym H. Sugar tax is already producing results. BBC News 2018 Mar. 12. Available: www.bbc.com /news/health-43372295 (accessed 2018 May 3).

13. Colchero MA, Rivera-Dommarco J, Popkin BM, et al. In Mexico, evidence of sustained consumer response two years after implementing a sugarsweetened beverage tax. Health Aff (Millwood) 2017;36:564-71.

Competing interests: Manuel Arango is the Director of Health Policy \& Advocacy at Heart \& Stroke, an organization that has declared its strong support for a levy on sugary drinks in Canada as a tool to reduce their consumption. No other competing interests were declared. 